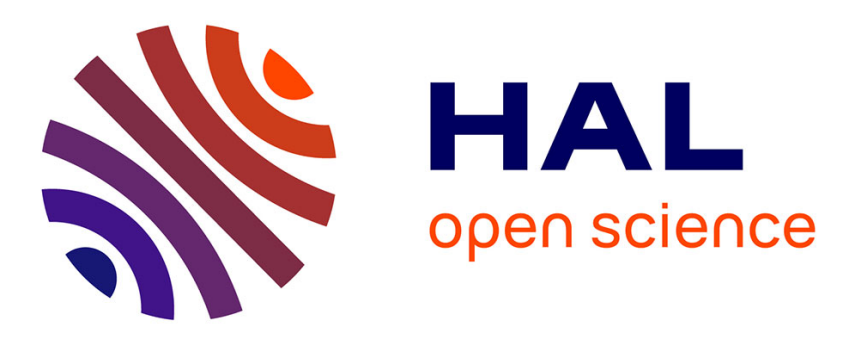

\title{
Synthesis of Spiroindolenines via Regioselective Gold(I)-Catalyzed Cyclizations of N -Propargyl Tryptamines
}

Valentin Magné, Angela Marinetti, Vincent Gandon, Arnaud Voituriez, Xavier Guinchard

\section{To cite this version:}

Valentin Magné, Angela Marinetti, Vincent Gandon, Arnaud Voituriez, Xavier Guinchard. Synthesis of Spiroindolenines via Regioselective Gold(I)-Catalyzed Cyclizations of N -Propargyl Tryptamines. Advanced Synthesis and Catalysis, 2017, 359 (22), pp.4036-4042. 10.1002/adsc.201700932 . hal03405398

\section{HAL Id: hal-03405398 \\ https://hal.science/hal-03405398}

Submitted on 2 Nov 2021

HAL is a multi-disciplinary open access archive for the deposit and dissemination of scientific research documents, whether they are published or not. The documents may come from teaching and research institutions in France or abroad, or from public or private research centers.
L'archive ouverte pluridisciplinaire HAL, est destinée au dépôt et à la diffusion de documents scientifiques de niveau recherche, publiés ou non, émanant des établissements d'enseignement et de recherche français ou étrangers, des laboratoires publics ou privés. 


\title{
Synthesis of Spiroindolenines via Regioselective Gold(I)- Catalyzed Cyclizations of $\boldsymbol{N}$-Propargyl Tryptamines
}

\author{
Valentin Magné, ${ }^{\mathrm{a}}$ Angela Marinetti, ${ }^{\mathrm{a}}$ Vincent Gandon, ${ }^{\mathrm{a}, \mathrm{b} *}$ Arnaud Voituriez ${ }^{\mathrm{a}}$ and \\ Xavier Guinchard ${ }^{\text {a* }}$
}

a Institut de Chimie des Substances Naturelles, CNRS UPR 2301, Univ Paris-Sud, Université Paris-Saclay, 1 av. de la Terrasse, 91198 Gif-sur-Yvette, France. E-mail: xavier.guinchard@cnrs.fr

b Institut de Chimie Moléculaire et des Matériaux d'Orsay, CNRS UMR 8182, Univ Paris-Sud, Université ParisSaclay, bâtiment 420, 91405 Orsay cedex, France. E-mail: vincent.gandon@u-psud.fr

\begin{abstract}
N}$-Propargyl tryptamines bearing $\mathrm{N}$-substituents such as propargyl, allyl, alkyl or benzyl groups undergo regioselective gold-catalyzed cyclizations to the corresponding spiroindolenines, while it was previously shown that $N$-sulfonyl- $N$-propargyl tryptamines lead to achiral azepino[4,5-b]indoles. An asymmetric approach to these spiroindolenines is disclosed using chiral gold complexes, leading to enantiomeric ratios up to $84 / 16$. The spiroindolenines could be late-stage functionalized using Huisgen cyclizations, palladium-catalyzed cross couplings or reductions. Computational studies show that the reaction evolves via different mechanistic pathways depending on the nature of the substituent at the amine.
\end{abstract}

Keywords: Alkynes, Gold catalysis; Indoles, Homogeneous catalysis, Spiro compounds

Transition metal-catalyzed dearomatization reactions are powerful tools for the synthesis of numerous heterocycles. ${ }^{[1]}$ In this regard, various catalysts have been used for the electrophilic activation of unsaturations tethered to indoles, leading to spiro compounds $^{[2]}$ exhibiting all-carbon quaternary centers. ${ }^{[3]}$ With their enhanced $\pi$-acidity, cationic gold(I) catalysts ${ }^{[4]}$ are particularly suitable to promote the activation of alkynes towards addition of indole nucleophiles. ${ }^{[5]}$ This strategy has been used for the synthesis of a number of diversely substituted polycyclic indolic compounds. ${ }^{6]}$ For instance, Echavarren reported the synthesis of azepino[4,5$b]$ indoles by cyclization of $N$-propargyl tryptamines in the presence of $A u(I)$ catalysts, ${ }^{[6 a, 6 b]}$ while $A u(I I I)$ catalysts lead mainly to tetrahydro- $1 \mathrm{H}$-azocino[5,4b]indoles (Scheme 1, eq. 1). ${ }^{[6 c]}$ All these compounds likely arise from the spiro intermediates shown in eq. 1 , that rearrange via a $\mathrm{C}-3$ to $\mathrm{C}-2$ migration,
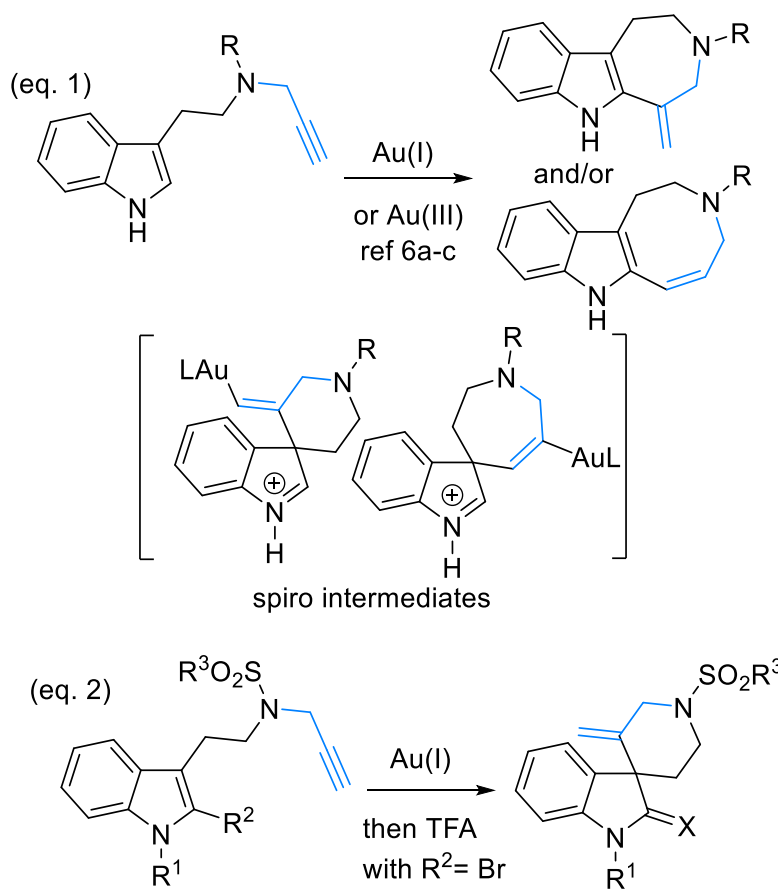
$\begin{array}{ll}\mathrm{R}^{1}=\mathrm{R}^{2}=\mathrm{Me}, \mathrm{R}^{3}=\mathrm{Ph}, \text { ref } 6 \mathrm{~b} & \mathrm{X}=\mathrm{CH} \\ \mathrm{R}^{1}=\mathrm{H}, \mathrm{R}^{2}=\mathrm{Br}, \mathrm{R}^{3}=p-\mathrm{NO}_{2} \mathrm{Ph}, \text { ref } 9 & \mathrm{X}=\mathrm{O}\end{array}$

$\mathrm{X}=\mathrm{CH}_{2}$

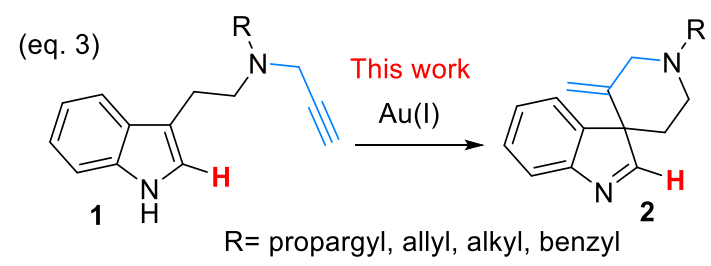

Scheme 1. Reported Gold-Catalyzed Cyclizations of $\mathrm{N}$ Propargyl Tryptamines and Present Synthetic Work

driven by restoration of aromaticity. ${ }^{[7]}$ However, Echavarren highlighted the crucial importance of the protecting groups of the tryptamine nitrogen in these reactions. Indeed, while $N$-propargyl- $N$ phenylsulfonyltryptamine (eq. $1, \mathrm{R}=\mathrm{SO}_{2} \mathrm{Ph}$ ) leads upon $\mathrm{Au}(\mathrm{III})$-catalysis to the tetrahydro- $1 \mathrm{H}$ azocino[5,4-b]indoles, the same reaction performed 
with $N$-propargyl- $N$-benzyl tryptamine (eq. 1, $\mathrm{R}=\mathrm{Bn}$ ) failed in providing any products. ${ }^{[8]}$

When the indole ring is substituted at the position 2, the putative spiro intermediate can be isolated as sole product after protodeauration (eq. $2, R^{1}=R^{2}=M e$ ). ${ }^{[6 b]}$ We recently took advantage of this reactivity using 2bromo- $N$-propargyl tryptamines in a sequence consisting in spirocyclization and hydrolysis of the 2bromospiroindolenine intermediate to deliver spirooxindoles (eq. $2, \mathrm{R}^{1}=\mathrm{H}, \mathrm{R}^{2}=\mathrm{Br}$ ). ${ }^{[9]}$

Incidentally, we recently discovered that $\mathrm{N}, \mathrm{N}$ dipropargyl tryptamine 1a (eq. 3, $\mathrm{R}=$ propargyl) could, however, undergo selective conversion into the spiroindolenine 2a upon Au(I)-catalysis (eq. 3). Spiroindolenines represent a class of compounds of high synthetic interest since this framework is present in a number of natural products and pharmaceutical agents. ${ }^{[10]}$ Importantly, such compounds are also precursors of spiroindolines upon reduction conditions or tetrahydro- $\beta$-carbolines by $\mathrm{C}-3$ to $\mathrm{C}-2$ migration. ${ }^{[11]}$

In this paper, we report our efforts in the development and the understanding of this unexpected reactivity with gold complexes and the late-stage functionalization of the corresponding spiroindolenines $\mathbf{2}$.

We initiated this work by establishing a gold(I)-based catalytic system enabling good selectivity for the dearomatized product $\mathbf{2} \mathbf{a}$, starting from dipropargyl tryptamine 1a. The Echavarren catalyst $\mathbf{4 a}^{[12]}$ furnished products $\mathbf{2 a}$ and $\mathbf{3 a}$ in a 9/1 ratio (Table 1 , entry 1 ). Compound 2 a was isolated in $64 \%$ yield.

Table 1. Optimization of the Catalytic System ${ }^{a}$

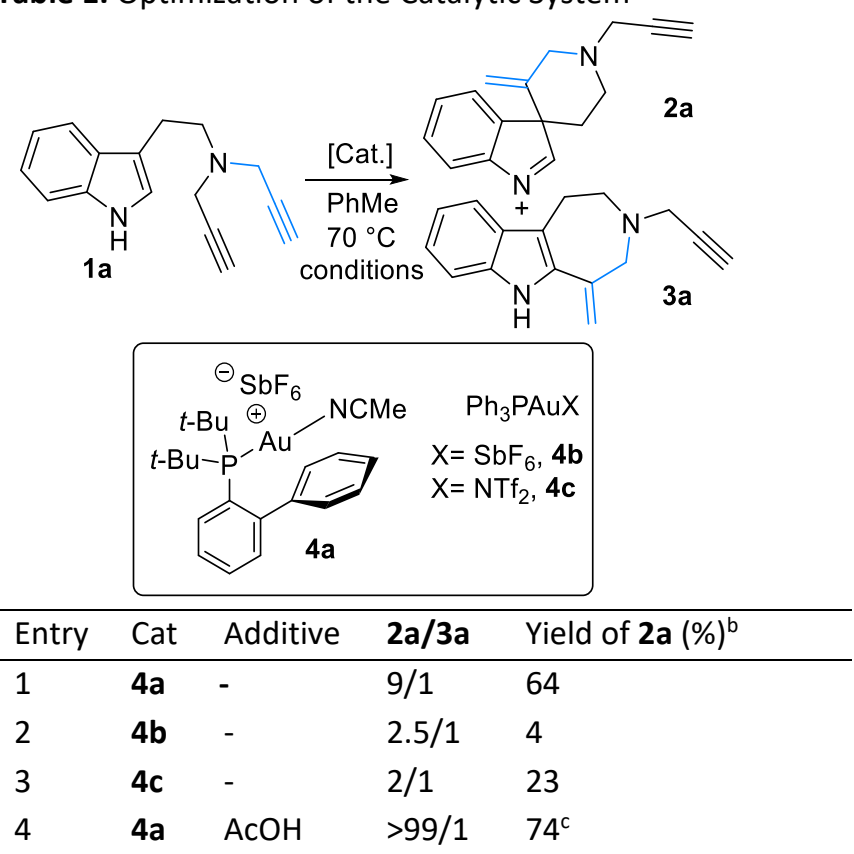

a Reaction conditions: 1 a $(0.1 \mathrm{mmol})$, cat. (5 mol\%), PhMe (0.1 M), $70{ }^{\circ} \mathrm{C}, 20 \mathrm{~h} .{ }^{\mathrm{b}}$ Yields were measured by ${ }^{1} \mathrm{H}$ NMR using trimethoxybenzene as internal standard. ${ }^{\mathrm{C}}$ Isolated yields.

Cationic triphenylphosphine gold complexes with either $\mathrm{SbF}_{6}^{-}$(4b) or $\mathrm{NTf}_{2}^{-[13]}$ (4c) as counterions furnished the products $\mathbf{2 a}$ and $\mathbf{3 a}$ in low yields and poor regioselectivities (entries 2 and 3 ). We next found that the addition of one equivalent of acetic acid to the reaction mixture with $\mathbf{4 a}$ as the catalyst had a beneficial effect, both on the regioselectivity and the yield, leading to a 99/1 ratio and an isolated yield of $2 a$ of $74 \%$ (entry 4). ${ }^{[14]}$ Performing the reaction at other temperatures, or the replacement of the acetic acid by PTSA or TFA did not improve this result (see the Supporting Information).

We then engaged various $N$-propargyl tryptamines 1 bearing different $\mathrm{R}^{1}$ and $\mathrm{R}^{2}$ groups with $5 \mathrm{~mol} \%$ of the Echavarren catalyst $4 \mathrm{a}$ at $70{ }^{\circ} \mathrm{C}$ in toluene, in the presence of one equivalent of acetic acid (Table 2). As previously shown in Table 1 , compound $\mathbf{2 a}$ was obtained in $74 \%$ yield and virtually full regioselectivity (Table 1, entry 4). Importantly, when the same reaction was performed on a gram-scale, a similar result was obtained $(62 \%, 615 \mathrm{mg}, 4.2 \mathrm{mmol}$, entry 1$)$. The reaction tolerates chloride, methoxy or methyl substituents at the position 5 of the indole, yielding compounds $\mathbf{2} \mathbf{b}$ and $\mathbf{2 c}$ as single products, and a mixture of $\mathbf{2 d}$ and $\mathbf{3 d}$ in a 92/8 ratio (entries 2-4).

Table 2. Scope of the Spirocyclization

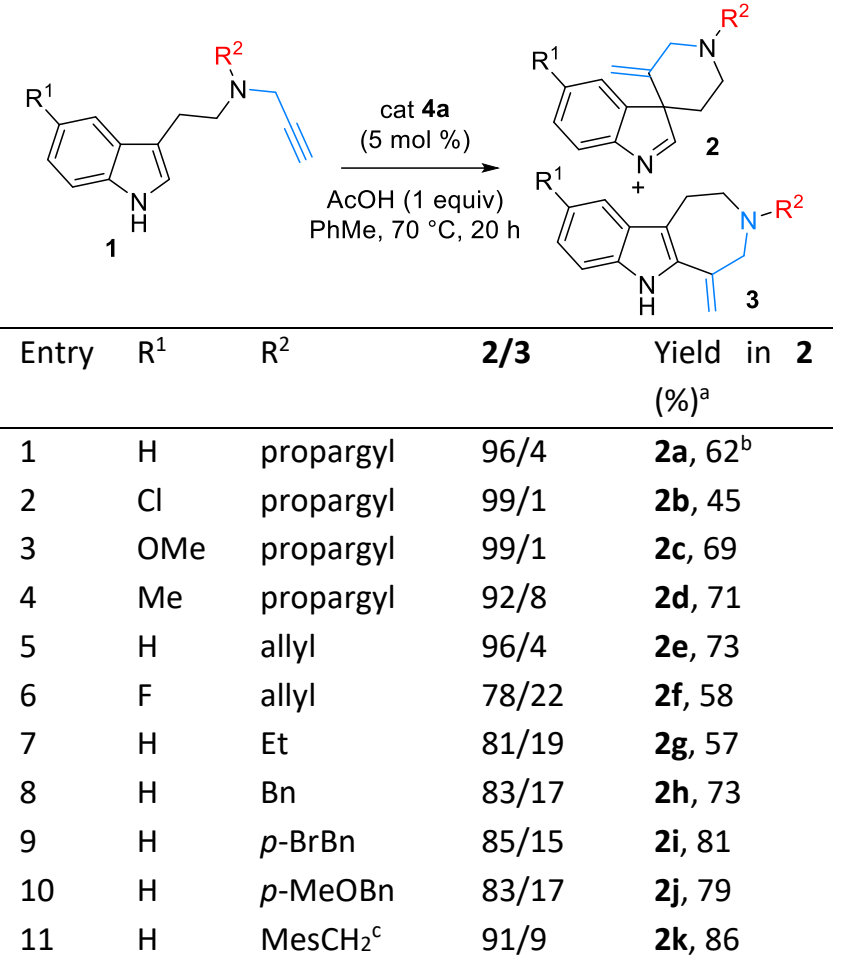


a Isolated yields of pure compounds $2 .{ }^{b}$ The reaction was performed on a gram scale. ' Mes stands for 2,4,6trimethylbenzene. ${ }^{\mathrm{d}}$ NAP stands for 1-naphthylmethyl.

The replacement of the spectator propargyl group by an ally ${ }^{[15]}$ allowed the synthesis of compounds $\mathbf{2} \mathbf{e}$ and $2 \mathbf{f}$ in good yields (entries 5 and 6 ). A slight erosion of the regioselectivity to $78 / 22$ was observed for fluorinated compounds 2f/3f (entry 6). When tryptamine $1 \mathrm{~g}$ bearing an ethyl group on the nitrogen was used, the corresponding spiroindolenine $\mathbf{2 g}$ was obtained in $57 \%$ yield. A $\mathbf{2 g} / \mathbf{3 g}$ ratio of $81 / 19$ was obtained (entry 7). We next used a series of $N$ propargyl tryptamines bearing benzyl groups on nitrogen. These compounds were previously reported to be unreactive towards $\mathrm{Au}(\mathrm{III})$ complexes. ${ }^{\left[{ }^{[6]}\right]}$ Under our reaction conditions using $\mathrm{Au}(\mathrm{I})$ complexes, the corresponding spiroindolenines $\mathbf{2} \mathbf{h}$-I were obtained in excellent yields. The $\mathbf{2 / 3}$ ratios were around $85 / 15$ (entries 8-12), with a notable improvement of the regioselectivity to $91 / 9$ with the bulky $\mathrm{CH}_{2} \mathrm{Mes}$ group of $\mathbf{2 k / 3 k}$ (entry 11 ).

The asymmetric spirocyclization of $\mathrm{N}$-propargyl tryptamines has not been reported under transition metal catalysis. ${ }^{[16]}$ We thought that chiral gold(I) catalysts ${ }^{[17]}$ might be suitable catalysts in this reaction and investigated the reaction of $\mathrm{N}, \mathrm{N}$-dipropargyl tryptamine $1 \mathrm{a}$, in the presence of gold complexes of chiral phosphorus ligands and silver bis(trifluoromethanesulfonyl)imide ${ }^{[18]}$ (Table 3). The TADDOL phosphoramidite-AuCl $\left(\mathbf{I}^{[17 \mathrm{c}, 19]}\right.$ displayed moderate catalytic activity, regioselectivity and enantioselectivity (entry 1 ). The use of $(R)$-DTBMMeO-BIPHEP-[AuCl] $]_{2}$ catalyst $\mathbf{I I}^{[17]}$ improved the enantioselectivity and the regioselectivity of the reaction, but still resulted in low conversion (entry 2 ), even when the reaction was performed in the presence of acetic acid (entry 3).We have introduced over the past few years phosphahelicenes as suitable ligands for asymmetric gold catalysis. ${ }^{[20]}$ Representative examples are complexes III, IV and V. The use of [HelPhos-P-AuCl] (III) as pre-catalyst increased the yield and resulted in a 79/21 enantiomeric ratio (entry 4). The [HelPhos-S-AuCl] (IV) was next used and compound $2 \mathbf{a}$ was obtained in $63 \%$ yield, in a good $2 a / 3 a$ ratio, with a $80 / 20$ er (entry 5). Interestingly, the use of [Ph-HelPhos-S-AuCl] (V) led to an increase of both the regioselectivity and the enantiomeric ratio to $84 / 16$ (entry 6). Thus, although the enantioselectivity remains moderate, phosphahelicenes showed higher performance than catalysts I and II.

Table 3. Asymmetric Au(I)-Catalyzed Cyclizations

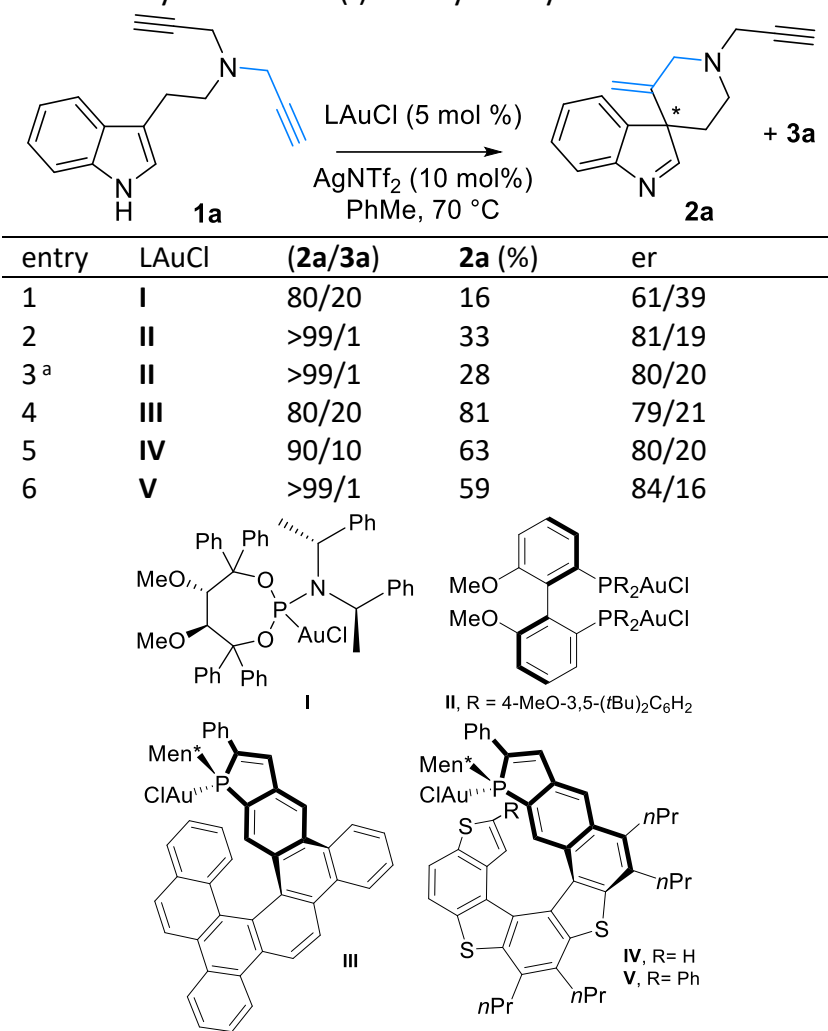

${ }^{\text {a }}$ Reaction performed in the presence of 1 equiv. of acetic acid.

We next studied the possible late-stage functionalization of products 2 by taking advantage of the different substituents on the nitrogen of the piperidine ring (Scheme 2). 


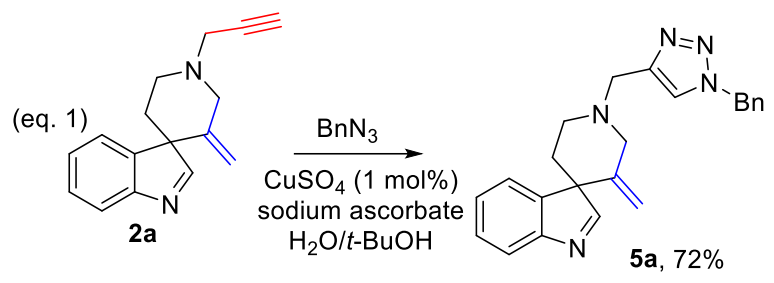

(eq. 2) 2

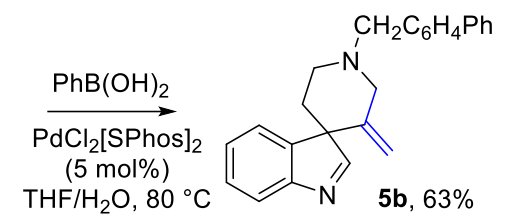

(eq. 3)

$2 a$
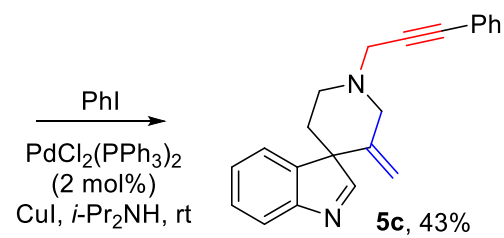

(eq. 4)

$2 a$
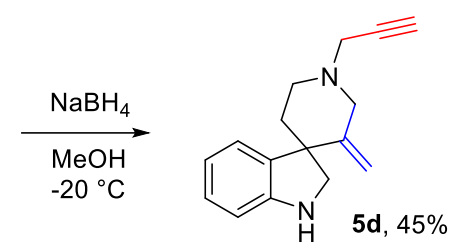

Scheme 2. Late-stage Functionalization of $\mathbf{2}$

Compound $2 \mathrm{a}$ was engaged in a click reaction with benzyl azide, which led to the triazole $5 a$ in $72 \%$ yield (Scheme 2, eq. 1). ${ }^{[21]}$ The $p$-bromophenyl function of indolenine $\mathbf{2} \mathbf{i}$ was used in a Suzuki cross-coupling reaction with $\mathrm{PhB}(\mathrm{OH})_{2}$ (eq. 2). The propargyl group of $2 a$ was also engaged in a Sonogashira reaction with phenyl iodide, leading to compound $\mathbf{5 c}$ (eq. 3). Lastly, the indolenine function could be reduced into the corresponding spiroindoline $\mathbf{5 d}$ by action of sodium borohydride in methanol at low temperature (eq. 4).

To get further understanding on the regioselectivity of the reaction and assess a plausible mechanism, we devised different scenarios that may explain the formation of compounds $\mathbf{2}$ and/or $\mathbf{3}$ (Scheme 3). Coordination of the gold complex to the propargyl group should allow the formation of intermediate $\mathbf{B}$ by addition of the nucleophilic indole to the alkyne, as previously suggested by Echavarren and Van der Eycken. ${ }^{[6 a, 6 b, 6 e]}$ Direct protodeauration would then lead to complex $\mathbf{C}$, while a 1,2-rearrangement could occur with the concomitant formation of the 7membered ring $\mathbf{D}$ that, after protodeauration and aromatization, would lead to the complex E.

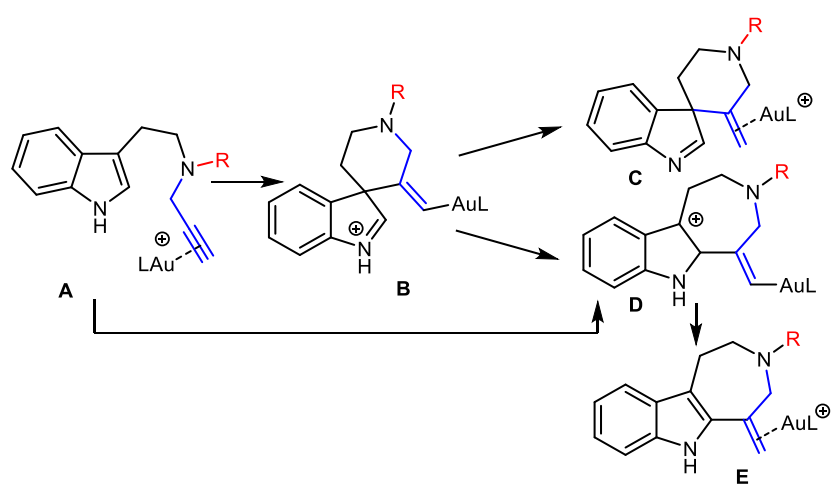

Scheme 3. Mechanistic Proposal

In order to support the viability of these hypotheses, we performed calculations on the postulated intermediates using the Gaussian 09 software package at the M06/def2-QZVP(Au)-6$311+G(2 d, p) / / B 3 L Y P / L A N L 2 D Z(A u)-6-31 G(d, p)$ level of density functional theory (See Supporting Information for details). Different $\mathrm{R}$ groups ( $\mathrm{R}=$ $\mathrm{PhSO}_{2}$, propargyl) were used to rationalize their influence on the regioselectivity. The Gibbs free energy profiles computed for these transformations are shown in Scheme 4. Complex $\boldsymbol{A}_{\boldsymbol{a}}$ bearing a propargyl group leads to complex $\mathbf{B}_{\mathbf{a}}$ with only 5.4 $\mathrm{kcal} / \mathrm{mol}$ of free energy of activation, and with a release $10.5 \mathrm{kcal} / \mathrm{mol}$ (blue curve). Complex $\mathbf{C}_{\mathrm{a}}$ lies at $-30.1 \mathrm{kcal} / \mathrm{mol}$ on the potential energy surface. The protodeauration that converts $\mathbf{B}_{\mathbf{a}}$ into $\mathbf{C}_{\mathbf{a}}$ is geometrically unworkable in an intramolecular fashion. Thus, this step probably occurs in an intermolecular manner with an unidentified proton shuttle, which could be a molecule of residual water or the counterion. Complex $\mathbf{B}_{\mathbf{a}}$ also can undergo a rearrangement to complex $\mathbf{D}_{\mathbf{a}}$ through an accessible transition state located $8.3 \mathrm{kcal} / \mathrm{mol}$ above $\mathbf{B}_{\mathbf{a}}$. Complex $\mathbf{D}_{\mathbf{a}}$ is less stable than $\mathbf{B}_{\mathbf{a}}$ by $4.0 \mathrm{kcal} / \mathrm{mol}$. The conversion of $\mathbf{D}_{\mathbf{a}}$ into $\mathbf{E}_{\mathrm{a}}$ could not be computed because it corresponds to a symmetry-forbidden 1,3$\mathrm{H}$ shift. However, it promotes a highly favorable release of free energy. Overall, $\mathbf{E}_{\mathrm{a}}$ is more stable than $C_{a}$ by $10.0 \mathrm{kcal} / \mathrm{mol}$ and lies $40.1 \mathrm{kcal} / \mathrm{mol}$ below the reference compound $\mathbf{A}_{\mathrm{a}}$. Nevertheless, the low amount of product 3 a recorded in each experiment suggests that the protodeauration of $\mathbf{B}$ leading to $\mathbf{C}$ is a faster process than the B-D-E pathway. Interestingly, the same pathway in the presence of protonated species seems even more favorable (pink curves). ${ }^{[22]}$ With only $1.8 \mathrm{kcal} / \mathrm{mol}$ barrier, the conversion of $\mathbf{A}_{b}$ to $\mathbf{B}_{b}$ releases $20 \mathrm{kcal} / \mathrm{mol}$ of free energy, which means an increase of $9.5 \mathrm{kcal} / \mathrm{mol}$ compared to the non-protonated series. Consequently, the rearrangement of $\mathbf{B}_{\mathbf{b}}$ to $\mathbf{D}_{\mathbf{b}}$ becomes more demanding in energy, with a barrier 


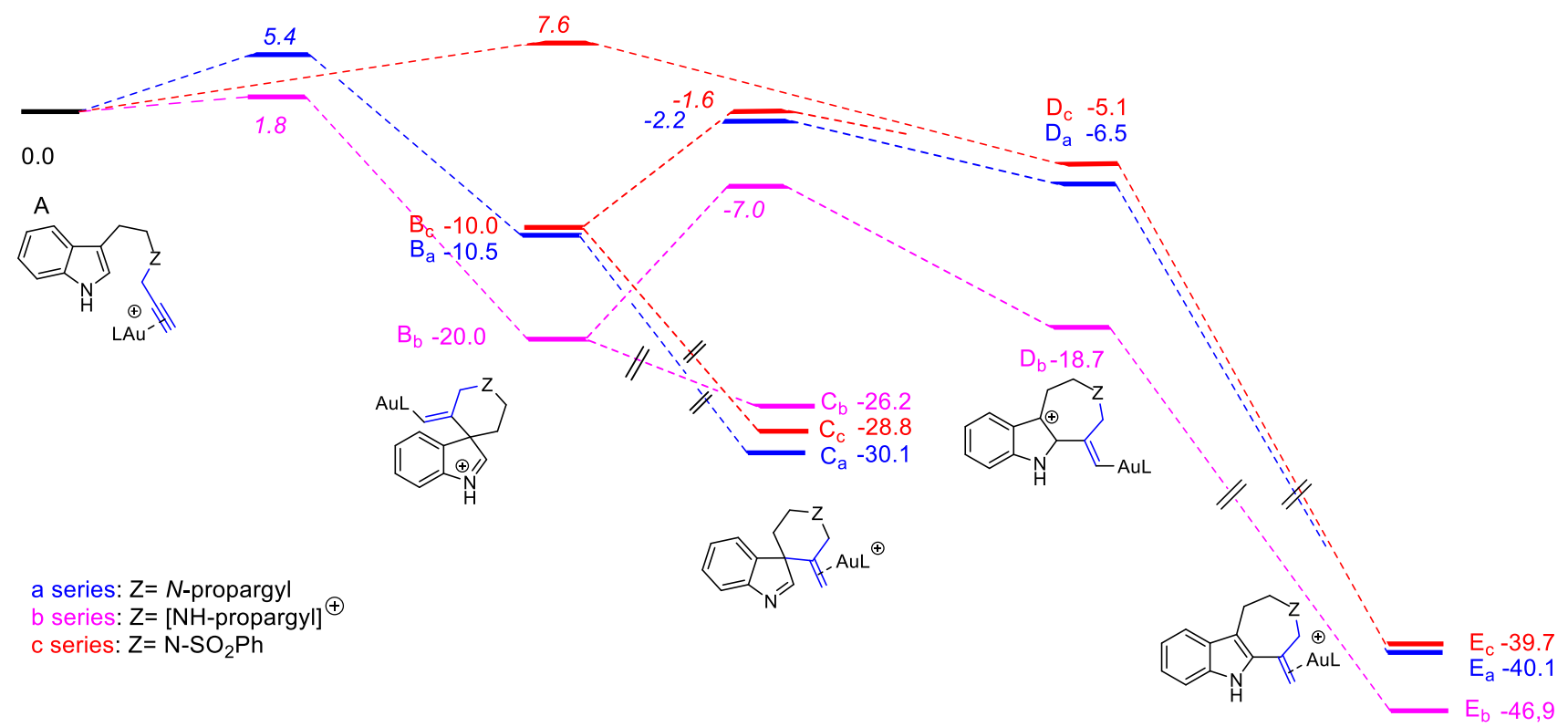

Scheme 4. Gibbs Free Energy Profiles ([ $G_{298}$, kcal/mol; $L$ = JohnPhos)

of $13.0 \mathrm{kcal} / \mathrm{mol}$, with again $\mathbf{D}_{\mathrm{b}}$ being less stable than $\mathbf{B}_{\mathbf{b}}$. In addition, it is worth to note that compound $\mathbf{2 a}$ is stable when submitted to the conditions of the reaction ( 5 mol\% $4 a, 1$ equiv. of $\mathrm{AcOH}, \mathrm{PhMe}, 70^{\circ} \mathrm{C}$ ), showing that the 1,2-migration is indeed possible only from the spiro vinyl gold species B. As discussed above, if the protodeauration step is fast enough, the reaction stops at intermediate $\mathbf{C}$, the rearrangement of $\mathbf{B}$ to $\mathbf{D}$ being less favorable. Beyond the effect of the adjunction of acid on the energetic pathway, it is also likely that the acid facilitates the protodeauration, ${ }^{[23]}$ thereby encouraging $\mathbf{C}$ over $\mathbf{D}$. [24],[25]

The phenylsulfonyl-substituted series (red curve) shed light on other connections between the different intermediates. While complex B was hypothesized as the actual intermediate, ${ }^{[6 a-b]}$ we could not find a direct connection between $\mathbf{A}_{\mathbf{c}}$ and $\mathbf{B}_{\mathbf{c}}$. On the contrary, a transition state connecting $\mathbf{A}_{\mathbf{c}}$ to $\mathbf{D}_{\mathbf{c}}$ could be found, occurring with a low barrier of 7.6 $\mathrm{kcal} / \mathrm{mol}$ and releasing $5.1 \mathrm{kcal} / \mathrm{mol}$ of free energy. Importantly, this direct transformation of $\mathbf{A}$ to $\mathbf{D}$ could not be found in any other series. $\mathbf{D}_{\mathbf{c}}$ can then evolve either through direct protodeauration and rearomatization to $E_{c}$, or ring contraction to $B_{c}$, with a barrier of only $3.5 \mathrm{kcal} / \mathrm{mol}$. The comparison between the transition states $\mathbf{T S}_{\mathrm{AaBa}}$ and $\mathbf{T S}_{\mathrm{AcDc}}$ shows a potential steric hindrance in the course of the cyclization between the $\mathrm{SO}_{2} \mathrm{Ph}$ group and the JohnPhos ligand due to $s p_{2}$ hybridization of the nitrogen atom, while with its $s p_{3}$ hybridization, the propargylamine group does not create any steric hindrance. ${ }^{[26]}$ This steric clash can be avoided in the transition state by elongating the

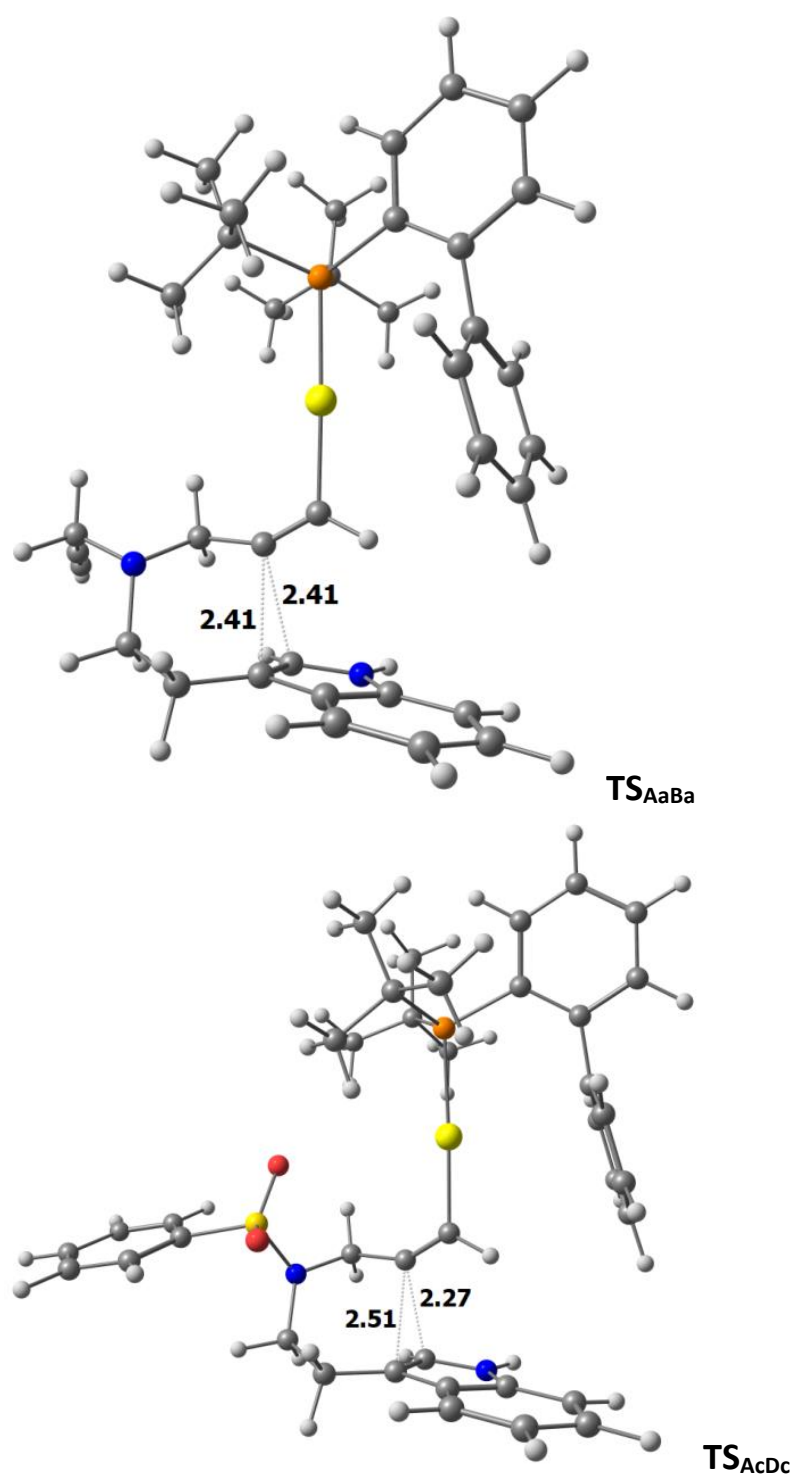


Figure 1. Computed Transition States for TS $\mathrm{S}_{\mathrm{ABB}}$ and $\mathrm{TS}$ AcDc

distance between the indole $\mathrm{C}-3$ and the internal alkyne carbon. As shown in Figure 1, this distance is of $2.41 \AA$ in $\mathbf{T S}_{\mathrm{AaBa}}$ and of $2.51 \AA$ in $\mathrm{TS}_{\mathrm{AcDc}}$. Thus, the sulfonyl group pushes the complexed alkyne towards C-2.

This set of calculations suggests that, provided the protodeauration is a fast step, the spiroindolenines $\mathbf{C}$ and the azepino[4,5-b]indoles $\mathbf{E}$ do not necessarily share a common spiro intermediate $\mathbf{B}$, depending on the nature of their $N$-substituent.

In conclusion, we have reported that $N$-propargyl, $N$ alkyl and $N$-benzyl $N$-propargyltryptamines afford spiroindolenines $\mathbf{2}$ rather than the previously reported azepino[4,5-b]indoles with high regioselectivities. The latter, which had been obtained with $N$-sulfonyl groups, seem to be a specific case. The dependence of the regioselectivity on the nature of the tether, i.e. $\mathrm{N}-\mathrm{SO}_{2} \mathrm{Ph}$ vs $\mathrm{NR}$, could be reproduced computationally. Preliminary studies were accomplished with chiral catalysts affording the spiroindolenines in a high 84/16 enantiomeric ratio. In addition, the synthesized spiroindolines could be easily late-stage-functionalized by click reaction, cross-coupling, or reduction. This paves the way for the access to potentially bioactive novel derivatives. In a more general context, while the gold catalysis involving amines is mostly performed with electronwithdrawing groups, this paper shows that alternative pathways may be discovered using basic, nucleophilic amines.

\section{Experimental Section}

General procedure for gold(I) catalyzed spirocyclization: $N$ propargyl-tryptamine 1 (0.1 $\mathrm{mmol})$ was placed into a Schlenck tube filled with argon. Toluene $(1.0 \mathrm{~mL})$ and acetic acid $(6.0 \mu \mathrm{L}, 0.1 \mathrm{mmol})$ were added and the stirred solution was warmed to $70{ }^{\circ} \mathrm{C}$ before adding catalyst $4 a(3.9 \mathrm{mg}$, $0.005 \mathrm{mmol}$ ). The reaction mixture was stirred for $20 \mathrm{~h}$ and then allowed to cool to RT before being concentrated under vacuum. Subsequent purification of the crude mixture over silica gel chromatography provided the product.

\section{3'-methylene-1'-(prop-2-yn-1-yl)spiro[indole-3,4'- piperidine] (2a).}

Compound $\mathbf{2 a}$ was synthetized following the general procedure using $N$-(2-(1H-indol-3-yl)ethyl)- $N$-(prop-2-yn-1yl)prop-2-yn-1-amine 1a (990 mg, $4.2 \mathrm{mmol}$ ). The desired spiroindolenine $\mathbf{2 a}$ was obtained after column chromatography on silica gel (gradient from 20 to $70 \%$ EtOAc:heptane) as a clear yellow oil $(615 \mathrm{mg}, 2.61 \mathrm{mmol}$, 62 \%). Rf: 0.37 (EtOAc). IR (neat) U max: 3291, 2919, 2808, $1646,1547,1464,1432,1329,1196,1133,1073,908,750$, 731, $645 \mathrm{~cm}^{-1} .{ }^{1} \mathrm{H}$ NMR $\left(\mathrm{CDCl}_{3}, 300 \mathrm{MHz}\right) \delta 8.36(\mathrm{brs}, 1 \mathrm{H})$, $7.68(\mathrm{~d}, J=7.7 \mathrm{~Hz}, 1 \mathrm{H}), 7.43(\mathrm{~d}, J=8.0 \mathrm{~Hz}, 1 \mathrm{H}), 7.39$ (td, $J=$ 7.7 and $1.5 \mathrm{~Hz}, 1 \mathrm{H}), 7.30(\mathrm{dd}, J=7.7$ and $1.5 \mathrm{~Hz}, 1 \mathrm{H}), 4.82$ (s, 1H), $4.60(\mathrm{~s}, 1 \mathrm{H}), 3.54(\mathrm{~d}, J=13.0 \mathrm{~Hz}, 1 \mathrm{H}), 3.54(\mathrm{~s}, 2 \mathrm{H})$, $3.39(\mathrm{~d}, J=13.0 \mathrm{~Hz}, 1 \mathrm{H}), 3.08(\mathrm{td}, J=11.8$ and $4.5 \mathrm{~Hz}, 1 \mathrm{H})$, $2.87(\mathrm{ddd}, J=12.0,10.4$ and $3.2 \mathrm{~Hz}, 1 \mathrm{H}), 2.37(\mathrm{t}, J=2.5 \mathrm{~Hz}$, 1H), 2.12 (ddd, $J=13.4,10.4$ and $4.1 \mathrm{~Hz}, 1 \mathrm{H}$ ), 1.77 (ddd, $J=$ 13.4, 5.2 and $3.3 \mathrm{~Hz}, 1 \mathrm{H}) .{ }^{13} \mathrm{C} \mathrm{NMR}\left(\mathrm{CDCl}_{3}, 75 \mathrm{MHz}\right) \delta 174.4$ $(\mathrm{CH}), 155.1\left(\mathrm{C}_{\mathrm{q}}\right), 141.2\left(\mathrm{C}_{\mathrm{q}}\right), 140.5\left(\mathrm{C}_{\mathrm{q}}\right), 128.5(\mathrm{CH}), 126.4$ $(\mathrm{CH}), 123.7(\mathrm{CH}), 122.0(\mathrm{CH}), 111.4\left(\mathrm{CH}_{2}\right), 78.1\left(\mathrm{C}_{\mathrm{q}}\right), 74.2$ $(\mathrm{CH}), 62.4\left(\mathrm{C}_{q}\right), 58.1\left(\mathrm{CH}_{2}\right), 50.5\left(\mathrm{CH}_{2}\right), 47.0\left(\mathrm{CH}_{2}\right), 33.5\left(\mathrm{CH}_{2}\right)$. HRMS (ESI): calcd for $\mathrm{C}_{16} \mathrm{H}_{17} \mathrm{~N}_{2}[\mathrm{M}+\mathrm{H}]^{+} 237.1386$, found 237.1394

\section{Acknowledgements}

VM thanks the ICSN for financial support. Nicolas Glinsky-Olivier and Dr Valérian Gobé (ICSN) are thanked for experimental assistance. We thank the ICSN and the IUF for financial support. We used the computing facility of the CRIANN (project 2006-013).

\section{References}

[1] For general reviews on dearomatizing cyclizations, see: a) A. R. Pape, K. P. Kaliappan, E. P. Kündig, Chem. Rev. 2000, 100, 2917; b) C.-X. Zhuo, W. Zhang, S.-L. You, Angew. Chem. Int. Ed. 2012, 51, 12662.

[2] a) S. P. Roche, J. A. Porco, Angew. Chem. Int. Ed. 2011, 50, 4068; b) S. P. Roche, J.-J. Youte Tendoung, B. Tréguier, Tetrahedron 2015, 71 , 3549; c) N. Denizot, T. Tomakinian, R. Beaud, C. Kouklovsky, G. Vincent, Tetrahedron Lett. 2015, 56, 4413; d) M. J. James, P. O'Brien, R. J. K. Taylor, W. P. Unsworth, Chem. Eur. J. 2015, 22, 2856; e) R. Dalpozzo, Chem. Soc. Rev. 2015, 44, 742.

[3] a) C. J. Douglas, L. E. Overman, Proc. Natl. Acad. Sci. 2004, 101, 5363; b) B. M. Trost, C. Jiang, Synthesis 2006, 2006, 369; c) T. Ling, F. Rivas, Tetrahedron 2016, 72, 6729.

[4] a) A. S. K. Hashmi, G. J. Hutchings, Angew. Chem. Int. Ed. 2006, 45, 7896; b) A. Arcadi, Chem. Rev. 2008, 108, 3266; c) E. Jimenez-Nunez, A. M. Echavarren, Chem. Rev. 2008, 108, 3326; d) A. Fürstner, Chem. Soc. Rev. 2009, 38, 3208; e) M. Chiarucci, M. Bandini, Beilstein J. Org. Chem. 2013, 9, 2586; f) A. Fürstner, Acc. Chem. Res. 2014, 47, 925; g) R. Dorel, A. M. Echavarren, Chem. Rev. 2015, 115, 9028.

[5] a) R. A. Widenhoefer, X. Han, Eur. J. Org. Chem. 2006, 2006, 4555; b) E. Jimenez-Nunez, A. M. Echavarren, Chem. Commun. 2007, 333; c) H. Huang, Y. Zhou, H. Liu, Beilstein J. Org. Chem. 
2011, 7, 897; d) M. Bandini, Chem. Soc. Rev. 2011, 40, 1358; e) H. Ohno, Isr. J. Chem. 2013, 53, 869; f) P. M. Barbour, L. J. Marholz, L. Chang, W. Xu, X. Wang, Chem. Lett. 2014, 43, 572.

[6] See, for example: a) C. Ferrer, A. M. Echavarren, Angew. Chem. Int. Ed. 2006, 45, 1105; b) C. Ferrer, C. H. M. Amijs, A. M. Echavarren, Chem. Eur. J. 2007, 13, 1358; c) C. Ferrer, A. Escribano-Cuesta, A. M. Echavarren, Tetrahedron 2009, 65, 9015; d) Y. Lu, X. Du, X. Jia, Y. Liu, Adv. Synth. Catal. 2009, 351, 1517; e) V. A. Peshkov, O. P. Pereshivko, E. V. Van der Eycken, Adv. Synth. Catal. 2012, 354, 2841 ; f) A. S. K. Hashmi, W. Yang, F. Rominger, Adv. Synth. Catal. 2012, 354, 1273; g) G. Cera, M. Chiarucci, A. Mazzanti, M. Mancinelli, M. Bandini, Org. Lett. 2012, 14, 1350; h) S. G. Modha, A. Kumar, D. D. Vachhani, J. Jacobs, S. K. Sharma, V. S. Parmar, L. Van Meervelt, E. V. Van der Eycken, Angew. Chem. Int. Ed. 2012, 51, 9572; i) J. D. Podoll, Y. Liu, L. Chang, S. Walls, W. Wang, X. Wang, Proc. Natl. Acad. Sci. 2013, 110, 15573; j) L. Zhang, Y. Wang, Z.-J. Yao, S. Wang, Z.-X. Yu, J. Am. Chem. Soc. 2015, 137, 13290; k) W. Xu, W. Wang, X. Wang, Angew. Chem. Int. Ed. 2015, 54, 9546.

[7] In a more general context, intramolecular cyclizations of indoles on electrophiles delivering 2-substituted products are often argued to evolve via spiroindolenines by $\mathrm{C}-3$ to $\mathrm{C}-2$ migrations. See refs 6a-f and also for examples: a) C.-X. Zhuo, Q.F. Wu, Q. Zhao, Q.-L. Xu, S.-L. You, J. Am. Chem. Soc. 2013, 135, 8169; b) C. C. J. Loh, G. Raabe, D. Enders, Chem. Eur. J. 2012, 18, 13250.

[8] There is however no mention of the catalytic activity of $A u(I)$ complexes on this substrate.

[9] V. Magné, F. Blanchard, A. Marinetti, A. Voituriez, X. Guinchard, Adv. Synth. Catal. 2016, 358, 3355.

[10] For selected examples, see: a) S. E. O'Connor, J. J. Maresh, Nat. Prod. Rep. 2006, 23, 532; b) T. Feng, Y. Li, X.-H. Cai, X. Gong, Y.-P. Liu, R.-T. Zhang, X.-Y. Zhang, Q.-G. Tan, X.-D. Luo, J. Nat. Prod. 2009, 72, 1836; c) D. Zhang, H. Song, Y. Qin, Acc. Chem. Res. 2011, 44, 447; d) W. Zi, Z. Zuo, D. Ma, Acc. Chem. Res. 2015, 48, 702.

[11] Spiroindolenines are putative intermediates in the Pictet-Spengler reaction, see for example: a) E. D. Cox, J. M. Cook, Chem. Rev. 1995, 95, 1797; b) J. Stockigt, A. P. Antonchick, F. R. Wu, H. Waldmann, Angew. Chem. Int. Ed. 2011, 50, 8538; c) R. Dalpozzo, Molecules 2016, 21, 699; d) R. N. Rao, B. Maiti, K. Chanda, ACS Comb. Sci. 2017, 19, 199; e) N. Glinsky-Olivier, X. Guinchard, Synthesis 2017, 49, 2605.

[12] C. Nieto-Oberhuber, S. Lopez, M. P. Munoz, D. J. Cardenas, E. Bunuel, C. Nevado, A. M. Echavarren, Angew. Chem. Int. Ed. 2005, 44, 6146.

[13] N. Mézailles, L. Ricard, F. Gagosz, Org. Lett. 2005, 7, 4133.
[14] It was checked that the acetic acid used in the absence of $A u(I)$ complex does not catalyze the cyclization

[15] We previously used extensively $N$-allyl tryptamines as precursors of numerous polycyclic indolic scaffolds: a) V. Gobé, X. Guinchard, Org. Lett. 2014, 16, 1924; b) V. Gobé, X. Guinchard, Chem. Eur. J. 2015, 21, 8511; c) V. Gobé, P. Retailleau, X. Guinchard, Chem. Eur. J. 2015, 21 , 17587; d) V. Gobé, M. Dousset, P. Retailleau, V. Gandon, X. Guinchard, Adv. Synth. Catal. 2016, 358, 3960.

[16] A single exemple of an asymmetric gold catalyzed reaction was reported using a $\mathrm{N}$-but-2-yn-4-olyl tryptamine derivative, see ref $6 \mathrm{~g}$. Nevertheless, iridium, ruthenium, copper or silver chiral complexes were used successfully in a few other reactions leading to spiroindolenines. For selected examples, see: a) Q.-F. Wu, H. He, W.-B. Liu, S.-L. You, J. Am. Chem. Soc. 2010, 132, 11418 ; b) X. Zhang, W.-B. Liu, Q.-F. Wu, S.-L. You, Org. Lett. 2013, 15, 3746 ; c) M. J. James, J. D. Cuthbertson, P. O'Brien, R. J. K. Taylor, W. P. Unsworth, Angew. Chem. Int. Ed. 2015, 54, 7640; d) J. T. R. Liddon, A. K. Clarke, R. J. K. Taylor, W. P. Unsworth, Org. Lett. 2016, 18, 6328.

[17] a) A. Pradal, P. Y. Toullec, V. Michelet, Synthesis 2011, 1501; b) W. Zi, D. F. Toste, Chem. Soc. Rev. 2016, 45, 4567; c) H. Teller, S. Flügge, R. Goddard, A. Fürstner, Angew. Chem. Int. Ed. 2010, 49, 1949; d) G. Cera, M. Bandini, Isr. J. Chem. 2013, 53, 848.

[18] It was checked that the reaction was not catalyzed by the silver salt. In addition, other silver salts investigated did not improve the results.

[19] H. Teller, M. Corbet, L. Mantilli, G. Gopakumar, R. Goddard, W. Thiel, A. Fürstner, J. Am. Chem. Soc. 2012, 134, 15331.

[20] a) K. Yavari, P. Aillard, Y. Zhang, F. Nuter, P. Retailleau, A. Voituriez, A. Marinetti, Angew. Chem. Int. Ed. 2014, 53, 861; b) P. Aillard, A. Voituriez, D. Dova, S. Cauteruccio, E. Licandro, A. Marinetti, Chem. Eur. J. 2014, 20, 12373; c) P. Aillard, P. Retailleau, A. Voituriez, A. Marinetti, Chem. Eur. J. 2015, 21, 11989; d) P. Aillard, D. Dova, V. Magne, P. Retailleau, S. Cauteruccio, E. Licandro, A. Voituriez, A. Marinetti, Chem. Commun. 2016, 52, 10984.

[21] a) Q. Wang, T. R. Chan, R. Hilgraf, V. V. Fokin, K. B. Sharpless, M. G. Finn, J. Am. Chem. Soc. 2003, 125, 3192; b) F. Himo, T. Lovell, R. Hilgraf, V. V. Rostovtsev, L. Noodleman, K. B. Sharpless, V. V. Fokin, J. Am. Chem. Soc. 2005, 127, 210.

[22] The protonation of the nitrogen atom leads to couples of isomers for each intermediates. The results are presented for one isomer. Full calculations are reported in the SI.

[23] P. Barrio, M. Kumar, Z. Lu, J. Han, B. Xu, G. B. Hammond, Chem. Eur. J. 2016, 22, 16410. 
[24] None of the functional group can assist the intramolecular proton transfer. For a discussion, see: B. Michelet, G. Thiery, C. Bour, V. Gandon, J. Org. Chem. 2015, 80, 10925.

[25] Previous studies showed that the presence of acid induced a reduction of the spirocyclic product in related silver-catalyzed processes, which supports in our case a very fast protodeauration which diminished the rate of 1,2-migration. See: M. J. James, R. E. Clubley, K. Y. Palate, T. J. Procter, A. C. Wyton, P. O'Brien, R. J. K. Taylor, W. P. Unsworth, Org. Lett. 2015, 17, 4372.
[26] E. Soriano, P. Ballesteros, J. Marco-Contelles, J. Org. Chem. 2004, 69, 8018. 
